Choose and Book and Hilda was told she would have a choice of four different hospitals (of course they didn't even attempt to consult me). Dr Greengage fed my details into the computer which took a little time to respond. Finally it turned out that there was a 3-month waiting list for any of the appointments. Hilda's reaction to this news was one of unaccustomed violence.

'I can't live with that thing for 3 months!' she said, pointing accusingly at me. 'Can't you just send for the pest control people and get rid of it?' Well I know this has all been very stressful for her, but really, what a thing to say. I think everyone was rather shocked. Then Dr Teacher said that Hilda's remark had given him an idea. He rummaged in the bottom drawer of his cupboard and came up with a large silver canister covered with strange black writing. 'Stand back everyone', he roared, as if about to do advanced resuscitation with a defibrillator. Then he pointed the canister at me and squeezed it. A jet of yellow vapour hit me full in the face and made me choke. I was blinded by the fumes and I thought I was going to die. Then the mist cleared and I found I was lying stretched out on the floor - but my human shape had been restored!

Dr Teacher explained to everyone that he had been given the canister by an old rabbi whom he had met at a medical humanities conference in Prague. Many times he had nearly thrown it away but something had always told him that it might come in useful one day. On the way home in the car Hilda and I were both silent until we turned into Chestnut Drive. Then, to my astonishment, she said, 'If you ever do that again l'm leaving you. Aren't you even going to apologise?'

I tried to explain that the transformation had been completely outside my control and was no way something I would wish to repeat. And I greatly regretted the distress it had caused her. She was somewhat mollified by my words and we agreed that the matter was now closed. I think that, provided nothing happens to me tonight, I will bring her a cup of tea in bed in the morning.

\title{
One of my heroes: Joe Porter
}

His transport as a medical officer in the first world war was a horse - in old age it was a fast car. As one of the eight doctors in Levenshulme in 1955 - four single handed and two partnerships of two, I remember it well. Our administrative body was called the Executive Council and Joe was their nightmare. He rarely replied to official correspondence and was repeatedly fined for not fulfilling his statutory obligations. He even failed to notify his acceptance of new patients - and was never paid for looking after them.

But his patients loved him - despite his wife!

Joe lived and practised in a semidetached Victorian house. His surgery was in the cellar approached down a slope at the side of the house. Unfortunately, Joe's wife was a retired matron whose character lived up to the cartoon image of ferocity then in fashion. She refused to open the waiting room door one second before time, so patients had to queue outside in every weather in a line that went under the kitchen window through which old Mrs Porter would throw her kitchen slops, So, sunshine or rain, patients queued under umbrellas.

Even after 2 years I hardly knew Joe, so I was surprised when one day his wife ordered me to his bedside. I found him in a simple bed with grey blankets in a poorly decorated room. It was only later on that I learnt of his lack of interest in wealth and possessions. I diagnosed congestive cardiac failure and recommended hospitalisation. Very reluctantly he agreed. Perhaps the thought of being nursed by his wife tipped his decision. I said I would look after his patients and he shouldn't worry. There was no question of him paying me. It was how medical etiquette worked in those days. And while he was in hospital I learnt what kind of doctor Joe was. One patient told me that, before the NHS when patients had to pay, he went to $\mathrm{Dr}$ Porter and said he couldn't afford anything that week. 'Never mind,' Joe said, and pulling half a crown from his waistcoat pocket, gave it to the patient saying - 'I think you need this more than I do.' I heard this story many times. Another patient told me that when he developed lobar pneumonia, $\mathrm{Dr}$ Porter went down on his knees by the bedside with the family and prayed that, on the fifth day when there would be a crisis, God would take into account all the good things this man had done. 'He gave me the will to live,' the patient said. 'He made me want to fight.' I soon realised that Joe did with words what I tried to do with diazepam - and Joe did it far better.

Soon after he died, one of Joe's patients came to my surgery. He was an older man, gentle, cap in hand across his chest, tears rolling down his face as he said - 'The doctor's dead. What shall I do?'

Joe is one of my heroes because he cared so deeply. Every patient was special. He understood them. He knew that what he called a symptom might mean one thing to him but something else to the patient. He treated illness as a family affair because incapacity in one person upsets the equilibrium of the family. If he didn't know what was wrong with someone, he'd move heaven and earth to find someone who did. He delivered babies and mourned at the grave. He won't go down in medical history as being a great doctor. He didn't discover anything new. He won't be remembered for lecturing to others on how things should be done. He had no 'cases' - only patients. Although he kept up to date with modern treatments, he regarded that as technical help in his role of looking after people in need.

\section{Stanley Jeffs}

DOI: 10.3399/bjgp08X342741 